\title{
ANALISIS SALURAN PEMASARAN KELAPA (Suatu Kasus di Desa Selasari Kecamatan Parigi Kabupaten Pangandaran)
}

\author{
ANALYSIS OF COCONUT MARKETING CHANNEL \\ (A Case in Selasari Village, Parigi Subdistrict, Pangandaran Regency)
}

JAJANG YULIAN*, AGUS YUNIAWAN ISYANTO, SUDRADJAT

Fakultas Pertanian Universitas Galuh

*Email: jajangyuliana9@gmail.com

\begin{abstract}
ABSTRAK
Penelitian ini bertujuan untuk mengetahui: (1) Saluran pemasaran kelapa, (2) Besarnya marjin pemasaran, (3) Keuntungan pemasaran, dan 4) Persentase harga yang diterima petani (farmer's share). Penelitian dilaksanakan di Desa Selasari Kecamatan Parigi Kabupaten Pangandaran dengan menggunakan metode survai. Sampel petani diambil dengan menggunakan simple random sampling sebanyak 31 orang dari 309 petani; sedangkan sampel pelaku pemasaran diambil dengan menggunakan snowball sampling. Hasil penelitian menunjukkan: (1) Terdapat dua saluran pemasaran, yaitu: Saluran I (petani $\rightarrow$ pedagang pengumpul $\rightarrow$ pedagang besar $\rightarrow$ pedagang pengecer $\rightarrow$ konsumen), dan Saluran II (petani $\rightarrow$ pedagang pengumpul $\rightarrow$ pedagang besar $\rightarrow$ konsumen), (2) Marjin pemasaran pada Saluran I Rp 2.200, sedangkan pada Saluran II Rp 2.800, (3) Keuntungan pemasaran pada Saluran I Rp 1.594,84, sedangkan pada Saluran II Rp 2.321,59, dan (4) Farmer's share pada Saluran I sebesar 57.69\%, sedangkan pada saluran II sebesar 44,00\%.
\end{abstract}

Kata kunci: Pemasaran, Kelapa, Farmer's share

This study aims to determine: (1) Coconut marketing channels, (2) Marketing margins, (3) Marketing profit, and 4) Farmer's share. The study was conducted in Selasari Village, Parigi Subdistrict, Pangandaran Regency using a survey method. Farmer samples were taken using simple random sampling of 31 people from 309 farmers; while the trader sample is taken using snowball sampling. The results showed: (1) There are two marketing channels, namely: Channel I (farmer $\rightarrow$ trader $\rightarrow$ wholesaler $\rightarrow$ retailer $\rightarrow$ consumer), and Channel II (farmer $\rightarrow$ trader $\rightarrow$ wholesaler $\rightarrow$ consumers), (2) Marketing margins in Channel I Rp 2,200, while in Channel II Rp 2,800, (3) marketing profits in Channel I Rp 1,594.84, while in Channel II Rp 2,321.59, and (4) Farmer's share in Channel I about $57.69 \%$, while in channel II about $44.00 \%$.

Keywords: Marketing, Coconut, Farmer's share

\section{PENDAHULUAN}

Sektor pertanian merupakan sektor yang sangat penting, baik dalam jangka panjang pembangunan ekonomi maupun untuk pemulihan ekonomi jangka pendek (Retno, 2017). Salah satu komoditas sector pertanian yang memberikan kontribusi yang cukup besar terhadap perekonomian nasional adalah komoditas kelapa. Tanaman kelapa adalah salah satu jenis tanaman perkebunan yang banyak ditanam oleh masyarakat perdesaan mengingat tanaman kelapa mempunyai peran yang besar bagi kehidupan masyarakat terutama sebagai sumber mata pencaharian. 
Tanaman kelapa dapat digunakan untuk kebutuhan pangan ataupun non pangan. Tanaman kelapa dan seluruh bagiannya bisa dimanfaatkan untuk kepentingan manusia, sehingga pohon kelapa dianggap sebagai tanaman serbaguna karenanya tanaman ini mempunyai nilai ekonomi tinggi.

Suksesnya agribisnis tergantung pada keberhasilan pemasarannya sehingga petani harus menempuh jalur-jalur pemasaran yang tepat untuk dapat meraih keuntungan. Hal penting dalam pemasaran produk pertanian adalah konsistensi masing-masing pihak untuk menjalankan fungsinya dan pembagian imbalan secara adil, sehingga pendapatan petani lebih rendah dari lembaga pemasaran. Kondisi tersebut ditimbulkan karena kurang efisiennya saluran pemasaran (Fathoni dkk, 2017)).

Penelitian ini bertujuan untuk mengetahui: (1) Saluran pemasaran kelapa di Desa Selasari Kecamatan Parigi Kabupaten Pangandaran, (2) Besarnya marjin pemasaran kelapa di Desa Selasari Kecamatan Parigi Kabupaten Pangandaran, (3) Besarnya keuntungan pemasaran kelapa di Desa Selasari Kecamatan Parigi Kabupaten Pangandaran, dan (4) Bagian harga yang diterima petani (Farmer's share).

\section{METODE PENELITIAN}

Jenis penelitian yang digunakan dalam penelitian ini adalah metode survai dengan mengambil kasus di Desa Selasari Kecamatan Parigi Kabupaten Pangandaran. Menurut Nazir (2011), metode survai adalah penyelidikan yang diadakan untuk memperoleh fakta-fakta dari gejala-gejala yang ada dan mencari keteranganketerangan secara faktual, baik tentang institusi sosial, ekonomi, atau politik dari suatu kelompok ataupun suatu daerah. Menurut Priyono (2008), pada umumnya yang merupakan unit analisis dalam penelitian survai adalah individu. Dalam pelaksanaannya menggunakan kuesioner sebagai instrumen penelitian yang berupa lembaran yang berisi beberapa pertanyaan dengan struktur yang baku.

Sampel petani sebanyak 31 orang atau $10 \%$ dari populasi 309 orang yang diambil dengan menggunakan simple random sampling. Menurut Suprapto (2017), simple random sampling adalah sebuah sampel yang diambil sedemikian rupa sehingga tiap unit penelitian atau satuan elementer dari populasi mempunyai kesempatan yang sama untuk dipilih sebagai sampel; atau dengan kata lain, setiap elemen dalam populasi mempunyai peluang yang sama untuk dipilih sebagai subjek dalam sampel. 
Sampel untuk pedagang perantara ditentukan dengan menggunakan snowball sampling. Menurut Sugiyono (2010), snowball sampling adalah teknik pengumpulan sampel yang mula-mula jumlahnya kecil kemudian membesar.

Saluran pemasaran kelapa dianalisis secara deskriptif dengan menelusuri produk dari produsen sampai ke konsumen. Marjin pemasaran dihitung dengan menggunakan persamaan:

$\mathrm{MP}=\mathrm{Hj}-\mathrm{Hb}$

Dimana:

MP = Marjin Pemasaran (Rp/butir)

$\mathrm{Hj}=$ Harga Jual (Rp/Butir)

$\mathrm{H}=$ Harga Beli (Rp/Butir)

Keuntungan pemasaran dihitung dengan menggunakan persamaan berikut:

$\pi=\mathrm{M}-\mathrm{B}$, atau $\mathrm{B}=\mathrm{M}-\pi$

Diimana:

$\pi=$ Keuntungan Pemasaran

$\mathrm{M}=$ Marjin Pemasaran

$\mathrm{B}=$ Biaya Pemasaran

Biaya pemasaran kelapa dihitung dengan menggunakan persamaan berikut:

$\mathrm{B}=\sum \mathrm{Bp}+\mathrm{BBM}+\mathrm{BR}+\mathrm{BPR}+\mathrm{B} 1$
Dimana:

$$
\begin{aligned}
& \mathrm{B}=\text { Biaya } \\
& \mathrm{BP}=\text { Biaya Pengangkutan } \\
& \mathrm{BBM}=\text { Biaya Bongkar Muat } \\
& \mathrm{BR}=\text { Biaya Retribusi } \\
& \mathrm{BPR}=\text { Biaya Penanggungan Resiko } \\
& \mathrm{B} 1=\text { Biaya lain-lain }
\end{aligned}
$$

Bagian harga yang diterima petani (farmer's share) dihitung dengan menggunakan persamaan berikut:

$\mathrm{FSi}=\mathrm{HP}: \mathrm{HE} \times 100 \%$

Dimana:

Fsi $=$ Bagian harga yang diterima petani $\mathrm{HP}=$ Harga di tingkat produsen $\mathrm{HE}=$ Harga di tingkat pceran

\section{HASIL DAN PEMBAHASAN}

\section{Saluran Pemasaran}

Lembaga pemasaran yang terkait dalam penyaluran kelapa dari produsen sampai ke tangan konsumen meliputi pedagang pengumpul, pedagang besar, dan pedagang pengecer. Terdapat dua saluran pemasaran kelapa di Desa Selasari Kecamatan Parigi Kabupaten Pangandaran sebagaimana terlihat pada Gambar 1.

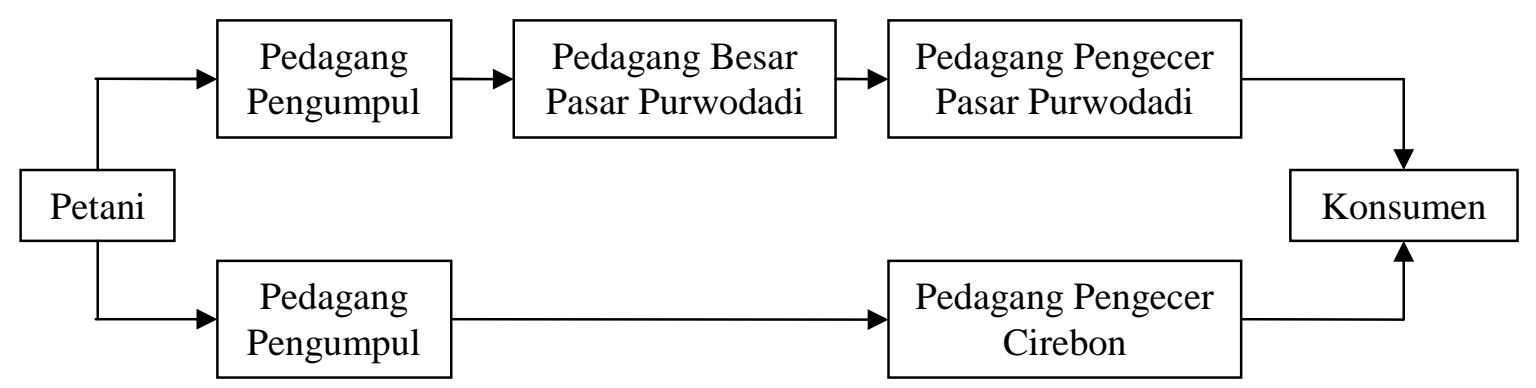

Gambar 1. Saluran Pemasaran kelapa di Desa Selasari Kecamatan Parigi Kabupaten Pangandaran 


\section{Marjin Pemasaran}

Marjin pemasaran pada masingmasing pelaku pemasaran di Saluran I adalah pedagang pengumpul sebesar $\mathrm{Rp}$ 1.100 per butir, pedagang besar Rp 600 per butir, dan pedagang pengecer di pasar Purwodadi sebesar Rp 500 per butir. Marjin pemasaran pada masing-masing pelaku pemasaran di Saluran II adalah pedagang pengumpul sebesar Rp 1.800 per butir dan pedagang pengecer di pasar Cirebon sebesar Rp 1.000 per butir.

\section{Keuntungan Pemasaran}

Keuntungan yang diperoleh lembaga pemasaran pada Saluran I adalah sebagai berikut: keuntungan pedagang pengumpul Rp 778,14 per butir, pedagang besar Rp 451.46 per butir, dan pedagang pengecer Rp 365,24 per butir. Keuntungan pemasaran pada saluran II adalah sebagai berikut: pedagang pengumpul Rp 1.443,58 per butir dan pedagang pengecer $\mathrm{Rp}$ 878,01 per butir.

\section{Farmer's Share}

Farmer's share adalah perbandingan harga yang diterima petani produsen dengan harga yang dibayarkan konsumen dikalikan $100 \%$. Untung ruginya para petani tidak ditentukan oleh besar kecilnya nilai farmer's share, tetapi dipengaruhi oleh harga produksi dan biaya yang dikeluarkannya.

Harga jual petani pada Saluran I sebesar Rp 3.000 per butir, sedangkan di tingkat pedagang pengecer sebesar Rp 5.200 per butir, sehingga farmer's share pada Saluran I sebesar 57,69\%.

Harga jual petani pada Saluran II sebesar Rp 2.200 per butir, sedangkan di tingkat pedagang pengecer sebesar $\mathrm{Rp}$ 5.000 per butir, sehingga farmer's share pada Saluran II sebesar $44,00 \%$.

\section{KESIMPULAN DAN SARAN}

\section{Kesimpulan}

1. Terdapat dua saluran pemasaran, yaitu: Saluran I (petani $\rightarrow$ pedagang pengumpul $\rightarrow$ pedagang besar $\rightarrow$ pedagang pengecer $\rightarrow$ konsumen), dan Saluran II (petani $\rightarrow$ pedagang pengumpul $\rightarrow$ pedagang besar $\rightarrow$ konsumen)

2. Marjin pemasaran pada masing-masing lembaga pemasaran di Saluran I: pedagang pengumpul Rp 1.100 per butir, pedagang besar Rp 600 per butir, dan pedagang pengecer Rp 500 per butir. Marjin pemasaran pada Saluran II: pedagang pengumpul Rp 1.800 per butir dan pedagang pengecer $\mathrm{Rp} 1.000$ per butir.

3. Keuntungan yang diperoleh masingmasing lembaga pemasaran pada Saluran I: pedagang pengumpul $\mathrm{Rp}$ 
778,14 per butir, pedagang besar $\mathrm{Rp}$ 451,46 per butir, dan pedagang pengecer Rp 365,24 per butir. Keuntungan pemasaran pada masingmasing lembaga pemasaran di Saluran II: pedagang pengumpul $\mathrm{Rp} 1.443,58$ per butir dan pedagang pengecer $\mathrm{Rp}$ 878,01 per butir.

4. Bagian harga yang diterima petani atau farmer's share pada Saluran I sebesar $57,69 \%$, sedangkan pada Saluran II sebesar $44,00 \%$.

\section{Saran}

Perlu adanya perbaikan fungsi pemasaran yaitu dalam hal pengumpulan dan pendistribusian kelapa dari produsen ke pedagang pengecer, mengingat masih tingginya biaya kerusakan yang terjadi dalam rangkaian biaya pemasaran kelapa dari daerah produsen sampai ke konsumen. Perbaikan yang dimaksud adalah perbaikan sarana penyimpanan dan sistem sortasi. Disarankan kepada pedagang pengecer untuk membeli kelapa langsung dari petani sehingga dapat mengurangi tingkat kerusakan kelapa

\section{DAFTAR PUSTAKA}

Fatoni, A., Rochdiani, D. dan Sudradjat. 2017. Efisiensi Pemasaran Pepaya (Carica papaya L.) Varietas Calina IPB-9 (Suatu Kasus di Kecamatan Langensari Kota Banjar). Jurnal Ilmiah Mahasiswa AGROINFO GALUH 4(1): 506-513.

Haddy Suprapto.2017. Metodologi PenelitiSan.

Gosyen

Publishing.Yogyakarta.

Nazir, M. 2011. Metode Penelitian. Bogor: Ghalia Indonesia.

Priyono.2008. Metode Penelitian Kuantitatif. Sidoarjo: Zifatama Publishing.

Retno, D .2017. Ekonomika Agribisnis. Jakarta: Griya Samata Permai.

Sugiyono.2010. Metode Penelitian Kuantitatif Kualitatif dan $R \& D$. Bandung: CV Alfabeta. 